Science of The Total Environment

Vol. 366, Issues 2-3, 1 August 2006, Pages 688-700

http://dx.doi.org/10.1016/j.scitotenv.2006.02.006

(c) 2006 Elsevier
Archimer, archive institutionnelle de l'lfremer http://www.ifremer.fr/docelec/

\title{
Mercury content in commercial pelagic fish and its risk assessment in the Western Indian Ocean
}

\author{
Jessica Kojadinovic ${ }^{a, \underline{b}, \underline{c},}$, Michel Potier ${ }^{\underline{d}}$, Matthieu Le Corre ${ }^{\underline{a}}$, Richard P. Cosson ${ }^{\underline{b}}$ and Paco \\ Bustamante ${ }^{\underline{c}}$ Auteurs
}

\author{
aUniversité de La Réunion, ECOMAR, Saint Denis, F-97715 France \\ bUniversité de Nantes, EMI, EA 2663, Nantes cedex3, F-44322 France \\ 'CRELA, UMR 6217, CNRS-IFREMER-Université de La Rochelle, La Rochelle, F-17042 France \\ ${ }^{\mathrm{d} I R D}, 97715$ Saint-Denis de La Réunion, France
}

Corresponding author : jessica.kojadinovic@univ-nantes.fr

\begin{abstract}
:
As top predators of pelagic food webs, large fish naturally bioaccumulate mercury $(\mathrm{Hg})$. Determining $\mathrm{Hg}$ burdens in commercialized fish is essential considering the concern about effects of contaminants on human health and the legal thresholds that are therefore set for local consumption and/or exportation. Total $\mathrm{Hg}$ levels were measured in the muscular tissue of 183 fish of five commercially important species from the tropical zone of the Western Indian Ocean. All individuals were measured and sexed in order to study the impregnation of $\mathrm{Hg}$ with size and sex within each species. Values of $\mathrm{Hg}$ found in this part of the Indian Ocean were comparable to $\mathrm{Hg}$ in muscular tissue of the same species studied in other areas. The highest $\mathrm{Hg}$ levels were noted in Swordfish (Xiphias gladius) caught in waters surrounding Reunion Island $\left(3.97 \pm 2.67 \mu \mathrm{g} \mathrm{g}^{-1}\right.$ dry weight). Following the Swordfish, in decreasing order of $\mathrm{Hg}$ content, were the Yellowfin Tuna (Thunnus albacares) and the Skipjack (Katsuwonus pelamis), then the Common Dolphinfish (Coryphaena hippurus) and the Wahoo (Acanthocybium solandri). In the North of the Mozambique Channel, Swordfish had higher Hg levels than Yellowfin Tunas, and Dolphinfish exhibited intermediate $\mathrm{Hg}$ levels. The size of a fish was a determining factor of its $\mathrm{Hg}$ burden, as was the species. Differences in size-normalized $\mathrm{Hg}$ levels were observed between the two study zones for Swordfish and Common Dolphinfish. Sex, in contrast, did not influence $\mathrm{Hg}$ levels suggesting that females and males have similar feeding habits. The muscular $\mathrm{Hg}$ levels presented here suggest that consumers of fish originating from theWestern Indian Ocean should limit themselves to one Swordfish based meal per week, or one fish meal a day if they choose to eat tuna or Common Dolphinfish.
\end{abstract}

Keywords: Mercury; Impregnation levels; Pelagic fish; Reunion Island; Mozambique Channel; Health standards 


\section{Introduction}

Historically, mercury $(\mathrm{Hg})$ has been used by many cultures for a variety of symbolic and useful purposes, such as in good luck charms, to ward off evil, as material for ceremony objects (Egyptians), as colorant and as cosmetics (Boudou, 1982; Mercury Task Force, 2002). Mercury played a predominant role in alchemy, and was thought to have medicinal uses such as curing syphilis in the 19th century (Dracobly, 2004). The large scale accidents of Minamata in the 1950's, and in Iraq in the early 1970's have, however, caught the world's attention on the potential toxicity of this metal. Much research has been conducted since, and health and ecological hazards are relatively well assessed today. The major anthropogenic $\mathrm{Hg}$ sources stem from its use in industries such as the manufacture of plastic, chlorine, caustic soda (sodium hydroxide), caustic potash (potassium hydroxide) and antifouling paint. Fossil fuel burning, base metal smelting, waste incinerators and $\mathrm{Hg}$ based fungicides used in agriculture are also important input sources of $\mathrm{Hg}$ in the environment. Natural sources of $\mathrm{Hg}$ include volcanic emissions, degassing from soils, and volatilization from the ocean. As a natural element, $\mathrm{Hg}$ is present as $\mathrm{Hg}$ vapors in the atmosphere, as inorganic $\mathrm{Hg}$ in the geosphere (to a very large extent encountered as mercuric sulphide cinnabar) and as inorganic or organic $\mathrm{Hg}$ in the hydrosphere. Among organic Hg species, methylmercury ( $\mathrm{MeHg}$ ) is the most abundant, and is bioaccumulated by aquatic organisms and biomagnified through the food chain.

Because of MeHg's trophic transfer property, organisms occupying high trophic positions and characterized by long lifespans, such as tuna fish and billfish are susceptible to contain high $\mathrm{Hg}$ burdens. Indeed, $\mathrm{Hg}$ found in fish is chiefly present as MeHg (Cappon and Smith, 1981; Bloom, 1992; Wagemann et al., 1997; Kehrig et al., 2002). The study of $\mathrm{Hg}$ impregnation in top predators is crucial as it serves as evidence for environmental exposure levels. Furthermore $\mathrm{Hg}$ burdens in large predatory fish are of particular interest because fish represent the major source of human exposure (Svensson et al., 1992).

To the best of our knowledge, there have been very few published studies on $\mathrm{Hg}$ in fish from the Western Indian Ocean (Kureishy et al., 1979). Fisheries of the Western Indian Ocean represent 5\% of worldwide catches. Tunas and associated species amount to approximately $30 \%$ of the catches in the Western Indian Ocean and $17 \%$ of worldwide tuna catches, which sets it in second place after the Pacific (Pianet, 1998). Among tunas and associated species, the major tunas, which include the Yellowfin (Thunnus albacares), the Skipjack

* Corresponding author. Tel : +(33) 2511256 91. Fax : +(33) 251125658.

ISOMer - Laboratoire de Biologie Marine, Faculté des Sciences et Techniques, Université de Nantes, 2 chemin de la Houssinière BP 92 208, 44322 Nantes, France.

Email address: jessica.kojadinovic@univ-nantes.fr (Jessica Kojadinovic). 
(Katsuwonus pelamis), the Bigeye (Thunnus obesus), the Albacore (Thunnus alalunga) and the Southern Bluefin (Thunnus maccoyii), are of particular importance for fisheries since they correspond to $70 \%$ of all catches in the Indian Ocean. Swordfish (Xiphias gladius) also stand out in fishery reports. Longliners based in Reunion Island have been specializing in Swordfish since the early 1990's, with catches amounting to 1741 tons per year in 2000. Total catches in the Western Indian Ocean exceed 20000 tons per year nowadays (Pianet, 1998). Furthermore, other species such as Wahoos (Acanthocybium solandri) and Common Dolphinfish (Coryphaena hippurus) are targeted by sport fisherman.

This paper provides new data for Hg levels in muscle of Swordfish, Yellowfin tunas, Skipjacks, Wahoos and Common Dolphinfish originating from the Southwestern Indian Ocean. Potential differences in $\mathrm{Hg}$ bioaccumulation between sexes were tested. Because $\mathrm{Hg}$ levels almost invariably increase with the size of the fish (e.g. Mackay et al., 1975; Monteiro and Lopes, 1990; Bloom, 1992; Dietz et al., 1996; Gilmour and Riedel, 2000; Stafford and Haines, 2001), length-adjusted $\mathrm{Hg}$ levels were used to compare the $\mathrm{Hg}$ impregnation of each species found in Reunion Island waters and in the North of the Mozambique Channel. Species Hg impregnations were also compared within study zones. Considering the nutritional value of fish and the large quantities consumed in this part of the world, our results were discussed in the light of international guidelines for $\mathrm{Hg}$ intake, and of potential health risk for the populations which feed on these fish.

\section{Materials and methods}

\subsection{Study site and species}

The samples of the five pelagic species studied during this investigation originated from two geographically distant sites in the Western Indian Ocean. The first site corresponds to waters surrounding Reunion Island, a $2512 \mathrm{~km}^{2}$ French territory located $700 \mathrm{~km}$ east of Madagascar $\left(21^{\circ} 7^{\prime} S ; 55^{\circ} 33^{\prime} \mathrm{E}\right)$. The second sampling zone was situated in the northern part of the Mozambique Channel, delimited by the following coordinates : $10^{\circ} 34^{\prime} S$ and $17^{\circ} 07^{\prime} S$, and $41^{\circ} 11^{\prime} E$ and $47^{\circ} 19^{\prime} E$ (Figure 1). These two sites correspond to two major fishing (seine and longline) areas of the Western Indian Ocean (Weenarain and Cayré, 1998).

The Swordfish is the largest of the sampled species averaging $165 \mathrm{~cm}$ LJLF (Lower Jaw Fork Length) in body length (FAO and SIDP, Oct. 2005). Females have a higher growth rate than males and therefore, reach greater lengths. In 


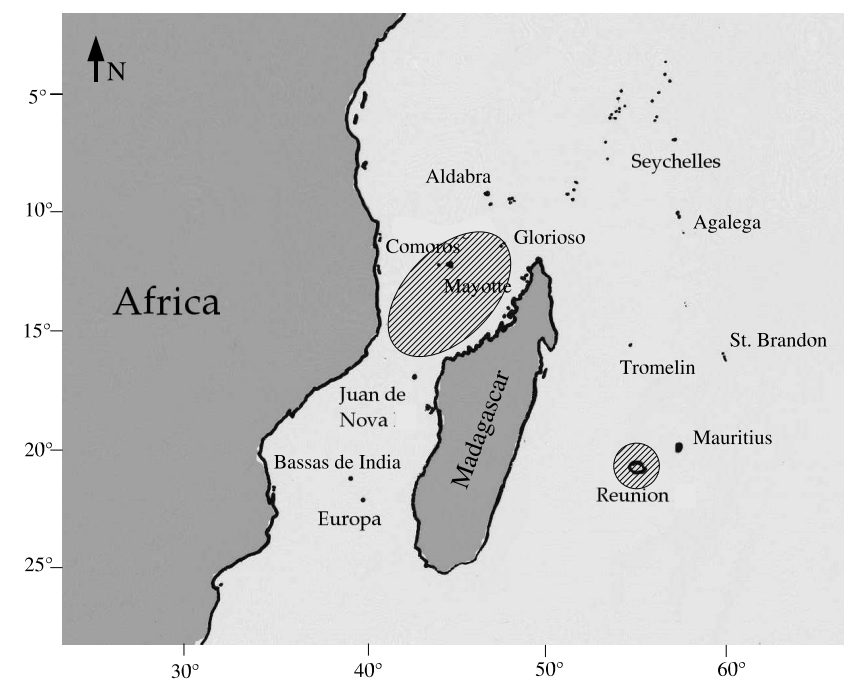

Fig. 1. Map of the study area with sampling zones materialized by shaded circles.

the Southwestern Indian Ocean, females may reach up to $250 \mathrm{~cm}$ LJLF, and males, up to $210 \mathrm{~cm}$ LJLF (Vanpouille et al., 2001). The Swordfish's lifespan is thought to be under 25 years (FAO and SIDP, Oct. 2005). Thirty-five thousand tons are fished in the Indian Ocean every year (Vanpouille et al., 2001).

Yellowfin tunas measure around $155 \mathrm{~cm}$ FL (Fork Length), but they can grow up to $240 \mathrm{~cm}$ FL and weigh up to $175 \mathrm{~kg}$ (NOAA fisheries, Oct. 2005). The maximum reported age is 8 years (FAO and SIDP, Oct. 2005). This species is the second most coveted by industrial and artisanal fisheries. The Western Indian Ocean basin is characterized by some of the largest quantities of Yellowfin tunas captures by seines and longliners in the world (around 300000 tons per year in 1994) (Pianet, 1998).

The Skipjack is the smallest tuna in the Indian Ocean. It usually weighs less than $5 \mathrm{~kg}$ and measures around $60 \mathrm{~cm}$ FL, although it can reach up to $30 \mathrm{~kg}$ and $100 \mathrm{~cm}$ FL in length (Stéquert and Marsac, 1986; Quéro and Vayne, 1997). Estimates of longevity vary between 8 and 12 years (FAO and SIDP, Oct. 2005). This species is the most commercialized tuna with more than 1000000 tons fished per year in the world, of which 200000 tons come from the Western Indian Ocean (Muus et al., 1998; Opic et al., 1994).

The maximum reported size for the Wahoo is $250 \mathrm{~cm}$ FL total length, with a maximum weight of $83 \mathrm{~kg}$. Typically, individuals attain a size of 100-170 $\mathrm{cm}$. It is believed that Wahoo lives up to 5-6 years of age (FAO and SIDP, Oct. 2005). Wahoo and other Seerfish annual catches approach 120000 tons in the Indian Ocean (Pianet, 1998).

The Common Dolphinfish is known to reach a maximum of $200 \mathrm{~cm}$ FL in length and $30 \mathrm{~kg}$ in weight, but it more commonly measures 50-100 $\mathrm{cm}$ FL 
and weighs $14 \mathrm{~kg}$. Longevity is estimated around 4 years (FAO and SIDP, Oct. 2005). Although they are not subject to specific fishing from longliners in the Western Indian Ocean, Common Dolphinfish commercialization is non negligible (Gaertner et al., 2001). This fish is also highly prized as a gamefish.

Since 1988, fish aggregation devices (FADs) have multiplied around Reunion Island, representing 85\% of coastal fishing by 1994 (Conand and Tessier, 1996). FADs characteristically concentrate young Yellowfin Tunas, Skipjacks, Wahoos and Dolphinfish.

\subsection{Fish sampling and mercury analysis}

A total of 65 fish (3 species) were caught with a traw line in the northern part of the Mozambique Channel and 118 fish (5 species) were collected by sport fishermen in Reunion waters. Each fish was measured, and weighed when possible. The Lower Jaw Fork Length (LJFL, from the tip of the lower jaw to the fork of the caudal fin) was measured on Swordfish whereas the Fork Length (FL, from the tip of the snout to the fork of the caudal fin) was noted for the others species. Individuals were sexed during dissection by the examination of the gonads. For practical reasons, white muscle was sampled for analysis in the abdominal area above the vent of the fish. We considered that $\mathrm{Hg}$ is uniformly distributed in fish edible muscle as it has been shown for Swordfish (Freeman and Home, 1973). The sampled muscle was conserved frozen at $-20^{\circ} \mathrm{C}$. It was then blended, dried in an oven at $50^{\circ} \mathrm{C}$ to constant mass and grounded to a fine powder. Glass and plastic utensils were washed with detergent, plunged in a bath of mixed nitric acid $\left(35 \mathrm{ml} . \mathrm{l}^{-1}\right)$ and chlorhydric acid $\left(50 \mathrm{ml} . \mathrm{l}^{-1}\right)$ for a minimum of $24 h$, rinsed 3 times in deionized (Milli-Q quality) water and dried in an oven at $50^{\circ} \mathrm{C}$ before use.

Total Hg analyzes were carried out with an Advanced Mercury Analyzer (combustion analyzer ALTEC 254) on aliquots ranging from 7 to $24 \mathrm{mg}$ of dried sample weighed to the nearest $0.01 \mathrm{mg}$. Accuracy of the preparation was tested by preparing replicate TORT-2 reference standards and blanks along with each set of samples. The detection limits and recovery rates of $\mathrm{Hg}$ were respectively equal to $0.0007 \mu g . g^{-1}$ and $101 \pm 3.5 \%$. Reproducibility was estimated as the closeness of 2 replicate measurements. The coefficient of variation given by relative standard deviations was always lower than 10\%. Element levels are expressed in $\mu g \cdot g^{-1}$ of dry weight (d.w.), and the mean moisture content of each tissue is provided in Table 1 . These values were used for the conversion of our results to wet weight $(w . w$.$) basis for comparison with other studies.$ 
Table 1

Percentage of water in the white muscle of pelagic fish from Reunion Island and the Mozambique Channel (mean \pm standard deviation).

\begin{tabular}{lcccc}
\hline & \multicolumn{3}{c}{ White muscle moisture content } \\
& $\mathrm{n}$ & Mozambique & $\mathrm{n}$ & Reunion \\
\hline Swordfish & 37 & $76 \pm 6$ & 7 & $69 \pm 8$ \\
Yellowfin Tuna & 20 & $75 \pm 2$ & 19 & $74 \pm 2$ \\
Skipjack Tuna & & - & 39 & $71 \pm 3$ \\
Wahoo & & - & 7 & $73 \pm 2$ \\
Common Dolphinfish & 5 & $82 \pm 3$ & 44 & $75 \pm 5$ \\
\hline
\end{tabular}

\subsection{Data analysis}

Prior to statistical analysis, bivariate plots of $\mathrm{Hg}$ levels against fish's lengths were visually examined for outliers. Statistical analysis were performed using the GNU R statistical system (R Development Core Team, 2005). All statistical samples submitted to tests were first checked for normality by means of Shapiro-Wilk tests. In the case of non-departure from normality, parametric tests were used in the subsequent analyzes, otherwise, non-parametric analogues were used.

The validity of the replicates of the level measures was tested by means of $t$-tests for paired samples. The influence of species on elemental levels was tested by means Kruskal-Wallis tests followed by Wilcoxon tests for independent samples using Bonferroni's $p$-value correction. The influence of sex and sampling location on $\mathrm{Hg}$ levels were tested by means of t-tests or Wilcoxon tests, after having checked samples for normality by means of Shapiro-Wilk tests.

Simple linear regression models (RMs) were estimated to explain the relationship between $\mathrm{Hg}$ and size. The best determination coefficients of $\mathrm{Hg}$ content against fish length regressions were obtained using logarithmic transformations of both variables. The RMs were thus realized on $\log \mathrm{Hg}$ values $\left(\mu g . g^{-1}\right.$ d.w.) and log lengths $(\mathrm{cm})$. RMs were also used to estimate the average size above which $\mathrm{Hg}$ content may exceed tissue levels that were used to set consumption advisories.

In most fish, muscle $\mathrm{Hg}$ content increases with the size of the individual (Mackay et al., 1975; Monteiro and Lopes, 1990; Bloom, 1992; Dietz et al., 1996; Gilmour and Riedel, 2000; Stafford and Haines, 2001). The difference in the average length of fish is thus a bias when comparing subsamples using comparison tests such as those described above. In order to truly measure the effect of other potential influencing factors such as the sampling location or the species, tested subgroups should contain fish of the same mean size. To test the influence of the location, an analysis of covariance (ANCOVA) was 
Table 2

Mean Hg levels ( $\mu g . g^{-1}$ d.w.), inter-specific and inter-locational comparisons results in pelagic fish from two areas of the tropical Western Indian Ocean. SD stands for standard deviation and CV for coefficient of variation. For each species, the significance of the $\mathrm{Hg}$ level differences among locations is given in the last column. In case of significant difference, the letters $a$ and $b$ are used to indicate which subgroups differ. Subgroups sharing the same letter do not differ significantly. The significance of the $\mathrm{Hg}$ level differences between species are given in the bottom line. In case of significant difference, the letters $\mathrm{X}, \mathrm{Y}$ and $\mathrm{Z}$, are used to indicate which subgroups differ.

\begin{tabular}{|c|c|c|c|c|c|c|c|c|c|}
\hline \multirow[b]{3}{*}{ Species } & \multicolumn{3}{|c|}{ Mozambique Channel } & & \multicolumn{3}{|c|}{ Reunion Island } & & \multirow{3}{*}{$\begin{array}{l}\text { Comparing } \\
\text { locations }\end{array}$} \\
\hline & \multirow[b]{2}{*}{$\mathrm{n}$} & Length $(\mathrm{cm})$ & $\mathrm{Hg}$ levels & & \multicolumn{2}{|r|}{ Length $(\mathrm{cm})$} & $\mathrm{Hg}$ levels & & \\
\hline & & $\begin{array}{c}\text { Mean } \\
(\min -\max )\end{array}$ & $\begin{array}{c}\text { Mean } \pm \text { SD } \\
\text { CV }(\%)\end{array}$ & & $\mathrm{n}$ & $\begin{array}{c}\text { Mean } \\
(\min -\max )\end{array}$ & $\begin{array}{c}\text { Mean } \pm \text { SD } \\
\mathrm{CV}(\%)\end{array}$ & & \\
\hline Swordfish & 37 & 123 & $1.61 \pm 1.11$ & $\mathrm{a} \mid \mathrm{Y}$ & 7 & 126 & $3.97 \pm 2.67$ & $\mathrm{~b} \mid \mathrm{X}$ & W: 0.002 \\
\hline Xiphias gladius & & $(75-191)$ & 69 & & & $(90-187)$ & 67 & & \\
\hline Yellowfin Tuna & 20 & 109 & $0.51 \pm 0.32$ & $\mathrm{a} \mid \mathrm{Z}$ & 19 & 104 & $0.70 \pm 0.49$ & aly & W: NS \\
\hline Thunnus albacares & & $(82-156)$ & 62 & & & $(49-170)$ & 70 & & \\
\hline Skipjack Tuna & 0 & & & & 39 & 68 & $0.67 \pm 0.26$ & $\mathrm{Y}$ & \\
\hline Katsuwonus pelamis & & & & & & $(41-85)$ & 39 & & \\
\hline $\begin{array}{l}\text { Wahoo } \\
\text { Acanthocybium solandri }\end{array}$ & 0 & & & & 7 & $\begin{array}{c}95 \\
(68-114)\end{array}$ & $\begin{array}{c}0.13 \pm 0.08 \\
62\end{array}$ & $\mathrm{z}$ & \\
\hline Common Dolphinfish & 5 & 109 & $0.98 \pm 0.92$ & $\mathrm{a} \mid \mathrm{YZ}$ & 44 & 87 & $0.21 \pm 0.19$ & $\mathrm{~b} \mid \mathrm{Z}$ & $\mathrm{W}:<0.001$ \\
\hline Coryphanea hippurus & & $(100-115)$ & 94 & & & $(61-112)$ & 91 & & \\
\hline Comparing species & & & $\mathrm{KW}:<0.001$ & & & & KW: $<0.001$ & & \\
\hline
\end{tabular}

performed for each species, in order to adjust the $\mathrm{Hg}$ levels in both sampling sites (Mozambique Channel and Reunion Island) using fish length as a covariate. The ANCOVA was also used to adjust the Hg levels in each species, using fish length as a covariate, to test whether size was the only explanatory factor of the differences observed between species. In the Mozambique Channel, Dolphinfish were excluded from the ANCOVA because of their very small sample size once the outliers were removed. The ANCOVAs were realized on $\log \mathrm{Hg}$ values and log lengths. Residuals were checked for normality by means of Shapiro tests, and for homocedaticity by plotting fitted values vs. residuals (Venables and Ripley, 2002; Faraway, 2005).

In an effort to facilitate the interpretation of the results we have adopted classical conventions throughout this paper. Kruskal-Wallis, ANCOVA, Wilcoxon and $t$ tests will be represented, respectively, by the following acronyms : $K W$, $A O C V, W$ and $t$.

\section{Results}

Summary statistics for $\mathrm{Hg}$ levels in the white muscle of each species caught in the Mozambique Channel and Reunion waters are presented in Table 2. 
Table 3

$\mathrm{P}$-values of pairwise $t$-tests or Wilcoxon tests for the comparison of $\mathrm{Hg}$ level in males and females of each species, in the Mozambique Channel and Reunion Island. (-) indicates subgroups for which samples had too few values to be tested.

\begin{tabular}{lcc}
\hline & \multicolumn{2}{c}{ Comparing sexual Hg levels } \\
& Mozambique & Reunion \\
\hline Swordfish & $\mathrm{W}: 0.286$ & - \\
Yellowfin Tuna & $\mathrm{W}: 0.115$ & $\mathrm{~W}: 0.142$ \\
Skipjack Tuna & & $\mathrm{t}: 0.135$ \\
Wahoo & & - \\
Common Dolphinfish & - & $\mathrm{W}: 0.925$ \\
\hline
\end{tabular}

Table 4

Regression models linking $\mathrm{Hg}$ levels $([\mathrm{Hg}])$ to length $(\mathrm{L}):[H g]=a \cdot L^{b}$.

\begin{tabular}{lccccc}
\hline Species & $\mathbf{n}$ & $\mathbf{a}$ & $\mathbf{b}$ & $\mathbf{r}^{2}$ & p-value \\
\hline Mozambique channel & & & & & \\
Swordfish & 37 & $9.142 \cdot 10^{-5}$ & 2.002 & 0.57 & $<0.001$ \\
Yellowfin Tuna & 20 & $1.224 \cdot 10^{-6}$ & 2.738 & 0.73 & $<0.001$ \\
Reunion & & & & & \\
Swordfish & 7 & $1.555 \cdot 10^{-3}$ & 1.570 & 0.44 & 0.105 \\
Yellowfin Tuna & 19 & $2.057 \cdot 10^{-4}$ & 1.713 & 0.40 & 0.008 \\
Skipjack Tuna & 39 & $6.961 \cdot 10^{-4}$ & 1.616 & 0.70 & $<0.001$ \\
Wahoo & 7 & $4.767 \cdot 10^{-8}$ & 3.227 & 0.75 & 0.011 \\
Common Dolphinfish & 44 & $8.850 \cdot 10^{-6}$ & 2.174 & 0.23 & 0.001 \\
\hline
\end{tabular}

Males and females were pooled since no influence of sex was revealed within the species-location subgroups which were tested (Table 3 ).

\subsection{Size-specific Hg levels}

The large individual variations in $\mathrm{Hg}$ levels within species-location subgroups (high CVs in Table 2) can be explained by the large range of sizes of the fish in each subgroup. Indeed, $\mathrm{Hg}$ levels were found to be positively correlated with the length of the fish (Figure 2). The relationships between the $\mathrm{Hg}$ levels $([\mathrm{Hg}])$ and the length $(\mathrm{L})$ were best fitted by the a regression of the form: $[H g]=a \cdot L^{b}$, where a and $\mathrm{b}$ are equation parameters estimated from the data and given for each species-location subgroup in Table 4. These regressions models were significantly better than constant models in all but one cases, Reunion Swordfish, probably because of a too small number of individuals. Besides, the model linking $\mathrm{Hg}$ and length in Mozambique Channel Dolphinfish is not given because of the excessively small sample size when ignoring the outliers. 

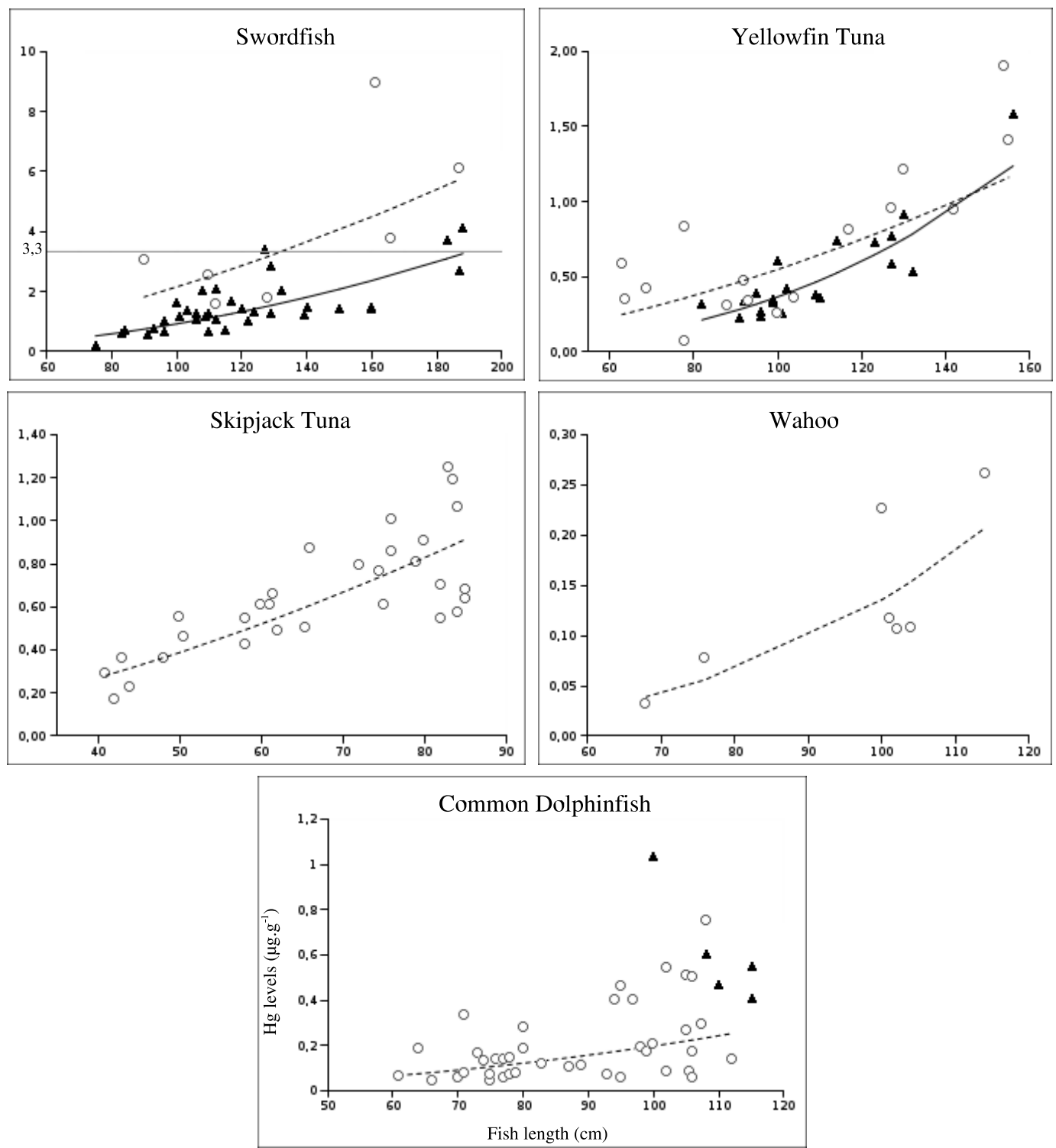

Fig. 2. Mercury levels $\left(\mu g \cdot g^{-1}\right.$ d.w.) against fish length $(\mathrm{cm})$. Mozambique and Reunion data are represented by $\boldsymbol{\Delta}$ and $\circ$ respectively, and the corresponding regression curves by full and dotted lines respectively. The gray horizontal line materializes the threshold level for human consumption $\left(1 \mu g \cdot g^{-1}\right)$ set by WHO.

\subsection{Site differences}

From the results given in Table 2 it appears as though the levels of muscular $\mathrm{Hg}$ differed between Swordfish and Common Dolphinfish caught in Reunion waters and those caught in the Mozambique Channel. However, the average size of the individuals collected in both zones were not identical (Table 2), and as it has been discussed in Section 3.1, $\mathrm{Hg}$ levels vary with the fish's length. ANCOVAs were realized, for Swordfish, in order to assess whether fish 
length differences alone explained the $\mathrm{Hg}$ levels variation noted between both sampling areas. The ANCOVA results indicated that the regression slopes of muscular Hg levels against fish length were not significantly different between areas $(p=0.548)$, but that the intercepts were significantly different $(p<$ 0.001). We may thus conclude that, for Swordfish, muscular $\mathrm{Hg}$ accumulates at the same rate with respect to length in both locations, but that $\mathrm{Hg}$ levels were different, with higher levels in Reunion Swordfish.

Despite the different ranges of sizes of Yellowfin Tunas sampled in the Reunion and Mozambique areas, $\mathrm{Hg}$ levels did not significantly differ between these two groups (Table 2). Non-significantly different regression slopes of $\mathrm{Hg}$ on fish length ( $A O C V: p=0.152)$ and non-significantly different intercepts ( $A O C V: p=0.051$ ) between areas confirmed that there were no $\mathrm{Hg}$ level differences between Mozambique Channel and Reunion Island fish, and that $\mathrm{Hg}$ was bioaccumulated at the same rate with respect to size in Yellowfin Tunas of both zones.

\subsection{Mercury level variations among species}

In both study areas, the Swordfish showed the highest $\mathrm{Hg}$ levels of all species. In Reunion, it was followed by the Yellowfin Tuna, the Skipjack, the Common Dolphinfish and the Wahoo in order of decreasing Hg burdens (Table 2). In the Mozambique Channel, the large sizes of the sampled Dolphinfish resulted in higher muscular $\mathrm{Hg}$ levels than in Yellowfin Tunas. A more extensive sampling of Dolphinfish in the Mozambique Channel would be necessary to better estimate $\mathrm{Hg}$ levels in this species.

ANCOVAs were realized, for both sites, to set aside the effect of length in order to assess whether other factors than length were responsible for the variations in $\mathrm{Hg}$ levels among species. In other words, would there still be differences in $\mathrm{Hg}$ burden among species if they all had the same average size? In both sites, the answer was positive, since the intercepts of the regression of $\mathrm{Hg}$ burdens against length were significantly different between species $(p<0.001)$. We may conclude that factors inherent to the species had an influence on $\mathrm{Hg}$ levels in these fish. Furthermore, the regression slopes of $\mathrm{Hg}$ burdens against length were the same for Swordfish and Yellowfin Tunas from the Mozambique Channel $(p=0.212)$ and for the five species from Reunion waters $(p=0.619)$. Hence, $\mathrm{Hg}$ levels in muscle seemed to be bioaccumulated at the same rate with respect to fish length in all species. 


\section{Discussion}

\subsection{Mercury, size, sex, species and location}

The size of a fish is known as a determining factor of its $\mathrm{Hg}$ burden (Mackay et al., 1975; Jaffar and Ashraf, 1988; Bloom, 1992; Dietz et al., 1996; Gilmour and Riedel, 2000; Stafford and Haines, 2001; Kraepiel et al., 2003), and has been confirmed here.

For Swordfish larger than $125 \mathrm{~cm}$ LJFL, females' growth rate is higher than that of male (Kume and Joseph, 1969; Quéro and Vayne, 1997; De Martini and Boggs, 1999; NOAA fisheries, Oct. 2005), and more generally, females are proportionally heavier than males of equal length (Ward and Elscot, 2000, Skilman \& Young 1974 in). It can be suspected that these physiological differences may affect length-Hg relations. In this study, no difference in $\mathrm{Hg}$ levels was observed in any of the five species. The influence of sex-differentiated growth rates between male and female Swordfish for individuals larger than $125 \mathrm{~cm}$ was probably diluted since very few fish were above this length: two females and two males among Reunion samples, and in the Mozambique Channel lot, only one female measured more than $125 \mathrm{~cm}$ in length.

According to the average sizes of the five teleost species investigated here (Section 2.1), the Swordfish is the largest followed by the Yellowfin Tuna, the Wahoo, the Common Dolphinfish and the Skipjack in decreasing order. In the Mozambique sample, the Common Dolphinfish had the same mean length as the Yellowfin Tunas, in consequence, their muscular Hg levels were not significantly different (Table 2 \& Figure 3). Among Reunion fish, Skipjacks had high $\mathrm{Hg}$ levels with respect to their size when compared to the other species (Figure 3). The opposite was observed for Wahoos. For example, Skipjacks caught around Reunion Island were smaller than Common Dolphinfish but exhibited higher $\mathrm{Hg}$ values, and Wahoos, which were in average larger than both of the latter, had the lowest $\mathrm{Hg}$ levels (Table 2). These interspecific differences in $\mathrm{Hg}$ levels were probably linked to differences in each species physiology, feeding rate, growth rate, lifespan, migratory patterns, foraging habits and/or diet. For instance, the low $\mathrm{Hg}$ levels in Wahoos could be explained by the surface foraging habits of this species $(0-12 \mathrm{~m})$ which contrasts with the others which feed from the surface to great depths (up to $800 \mathrm{~m}$ for Swordfish) where $\mathrm{Hg}$ methylation, in these poorly oxygenated waters, enhances its bioaccumulation (Monteiro et al., 1996; Kraepiel et al., 2003). A clear example of differential vertical distribution of $\mathrm{Hg}$ levels in fish is given by Monteiro et al. (1996), who found a 4-fold increase in $\mathrm{Hg}$ levels from epipelagic (100-150 $\mathrm{m}$ ) to mesopelagic (300-1 $200 \mathrm{~m}$ ) lanternfish species in the sub-tropical mid-North Atlantic. 

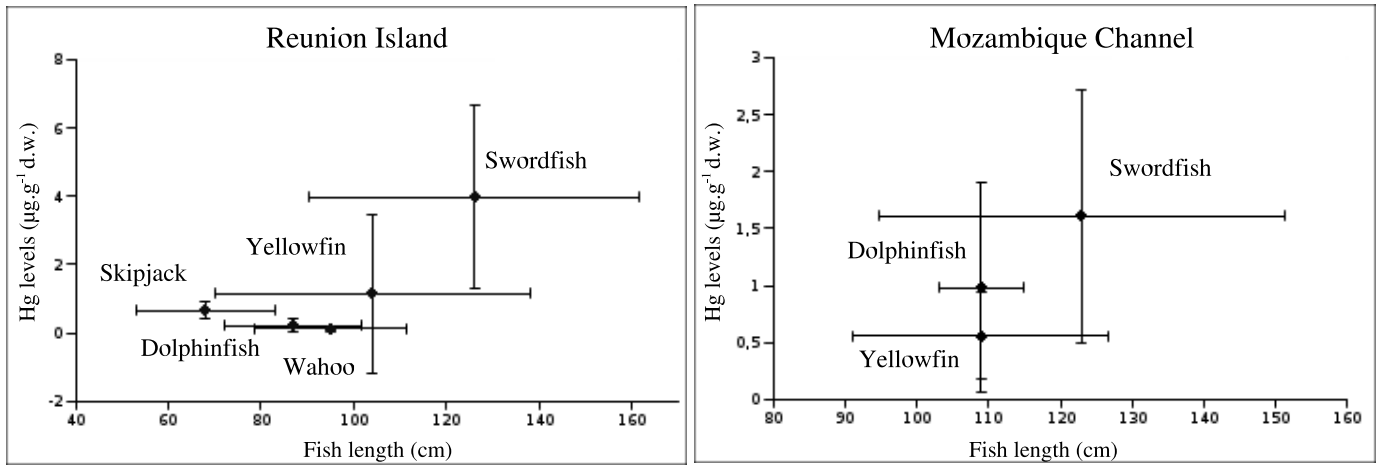

Fig. 3. Position of species in relation to their mean length and mean $\mathrm{Hg}$ levels in both study zones. Error bars represent the standard deviation.

Locational differences between the North of the Mozambique Channel and Reunion waters were confirmed for Swordfish. More data on Dolphinfish from the Mozambique Channel are needed to verify whether these fish have higher $\mathrm{Hg}$ burdens than those collected in Reunion waters, irrespectively of their size. If the latter is confirmed, it would go against the results obtained for Swordfish. Consequently, it could be hypothesized that the differences in fish $\mathrm{Hg}$ impregnation were due to differences in their dietary prey composition and/or in the trophic position they occupy in both areas, rather than differences in environmental $\mathrm{Hg}$ levels. Conversely, the intense volcanic activity on Reunion Island could account for higher $\mathrm{Hg}$ levels in Swordfish caught in the waters surrounding this island. This second hypothesis would be more likely if Dolphinfish did not show higher levels in the Mozambique Channel.

\subsection{Comparison with published data}

The $\mathrm{Hg}$ levels detected in pelagic fishes during this study were quite similar to phylogenetically related species from oceans around the world as shown in Table 5, especially given that the fish compared here vary in sizes. On the Southwestern Indian Ocean scale, Seychelles waters seem to be richer in $\mathrm{Hg}$ than the Mozambique Channel and Reunion waters, since Yellowfin Tunas, Skipjacks and Wahoos caught there had higher $\mathrm{Hg}$ levels than those analyzed in this study. These values are however relatively low in comparison with $\mathrm{Hg}$ levels that can be found in the muscular tissue of fish analyzed in polluted coastal areas, or in deep-water benthopelagic fish. For example, the small piscivorous Acestrorhynchus guianensis from the Amazon basin, which is polluted by goldmining, exibits $\mathrm{Hg}$ levels as high as $4.3 \mu g . g^{-1}$ d.w. (Durrieu et al., 2005). Furthermore, median Hg levels of $13 \mu g . g^{-1}$ d.w. were reported for the small deep-sea Smooth Grenadier, Nezumia aequalis, found in the 500$1750 \mathrm{~m}$ bathymetric zones of the Rockall Trough, North West of the British Isles (Mormede and Davies, 2001). The record of highest $\mathrm{Hg}$ levels in teleost 
Table 5

Mercury levels (Mean \pm Standard Deviation, $\mu g . g^{-1}$ wet weight) in muscle of marine fish from various geographical areas. ${ }^{*}$ indicates the locations for which data were transformed from dry weight to wet weight basis.

\begin{tabular}{|c|c|c|c|c|c|c|}
\hline Species & Origine & $\mathbf{n}$ & Sex & Weight/Length & Hg & References \\
\hline Swordfish & Mozambique Channel * & 37 & $\mathrm{~F} / \mathrm{M}$ & $21 \mathrm{Kg}$ & $0.38 \pm 0.26$ & This study \\
\hline \multirow[t]{5}{*}{ Xiphias gladius } & Reunion Is. * & 7 & $\mathrm{~F} / \mathrm{M}$ & $22 \mathrm{Kg}$ & $1.24 \pm 0.83$ & This study \\
\hline & Atlantic Ocean & 192 & $\mathrm{~F} / \mathrm{M}$ & - & $0.62 \pm 0.35$ & Mendez et al. 2001 \\
\hline & Atlantic Ocean & 88 & $\mathrm{~F}$ & - & $0.93 \pm 0.07$ & Monteiro \& Lopes 1990 \\
\hline & Atlantic Ocean & 48 & M & - & $1.30 \pm 0.17$ & Monteiro \& Lopes 1990 \\
\hline & Unidentified & 305 & $\mathrm{~F} / \mathrm{M}$ & - & 0.97 & FDA survey 1990-2002 \\
\hline Yellowfin Tuna & Mozambique Channel * & 20 & $\mathrm{~F} / \mathrm{M}$ & $22 \mathrm{Kg}$ & $0.13 \pm 0.09$ & This study \\
\hline \multirow[t]{5}{*}{ Thunnus albacares } & Reunion Is. * & 19 & $\mathrm{~F} / \mathrm{M}$ & $24 \mathrm{Kg}$ & $0.21 \pm 0.15$ & This study \\
\hline & Seychelles & 5 & - & $17 \mathrm{Kg}$ & $0.23 \pm 0.10$ & Matthews 1983 \\
\hline & Pacific Ocean & 105 & - & - & $0.21 \pm 0.11$ & Kraepiel et al. 2003 \\
\hline & Atlantic Ocean & 56 & $\mathrm{~F} / \mathrm{M}$ & $84 \mathrm{~cm} \mathrm{FL}$ & $0.25 \pm 0.12$ & Adams 2004 \\
\hline & Unidentified & 50 & - & - & $0.65 \pm 0.10$ & FDA survey 1990-2002 \\
\hline Bluefin Tuna & Arabian Sea & 17 & - & - & $0.08 \pm 0.01$ & Jaffar \& Ashraf 1988 \\
\hline \multicolumn{7}{|l|}{ Thunnus thynnus } \\
\hline Longtail Tuna & Arabian Sea & 18 & - & - & $0.03 \pm 0.01$ & Jaffar \& Ashraf 1988 \\
\hline \multicolumn{7}{|l|}{ Thunnus tonggel } \\
\hline Skipjack Tuna & Reunion Is. * & 39 & $\mathrm{~F} / \mathrm{M}$ & $9 \mathrm{Kg}$ & $0.19 \pm 0.66$ & This study \\
\hline \multirow[t]{2}{*}{ Katsuwonus pelamis } & Indian Ocean & 1 & M & - & 0.53 & Kureishy et al. 1979 \\
\hline & Seychelles & 5 & - & $5 \mathrm{Kg}$ & $0.34 \pm 0.11$ & Matthews 1983 \\
\hline Wahoo & Reunion Is. * & 7 & $\mathrm{~F} / \mathrm{M}$ & - & $0.10 \pm 0.08$ & This study \\
\hline \multirow[t]{2}{*}{ Acanthocybium solandri } & Seychelles & 5 & - & $16 \mathrm{Kg}$ & $0.57 \pm 0.41$ & Matthews 1983 \\
\hline & Indian Ocean & 4 & $\mathrm{~F} / \mathrm{M}$ & $5 \mathrm{Kg}$ & $0.11 \pm 0.03$ & Kureishy et al. 1979 \\
\hline Blue fin Tuna & Indian Ocean & 1 & $\mathrm{~F}$ & - & $0.12 \pm 0.01$ & Kureishy et al. 1979 \\
\hline \multicolumn{7}{|l|}{ Kishinoella tonggol } \\
\hline Common Dolphinfish & Mozambique Channel * & 5 & $\mathrm{~F} / \mathrm{M}$ & $9 \mathrm{Kg}$ & $0.17 \pm 0.16$ & This study \\
\hline \multirow[t]{5}{*}{ Coryphanea hippurus } & Reunion Is. * & 44 & $\mathrm{~F} / \mathrm{M}$ & $5 \mathrm{Kg}$ & $0.01 \pm 0.05$ & This study \\
\hline & Indian Ocean & 4 & $\mathrm{~F}$ & - & $0.07 \pm 0.004$ & Kureishy et al. 1979 \\
\hline & Indian Ocean & 1 & $\mathrm{~F}$ & - & $0.14 \pm 0.01$ & Kureishy et al. 1979 \\
\hline & Indian Ocean & 1 & $\mathrm{~F}$ & - & $0.12 \pm 0.01$ & Kureishy et al. 1979 \\
\hline & Unidentified & 18 & $\mathrm{~F} / \mathrm{M}$ & - & 0.18 & FDA survey 1990-2002 \\
\hline
\end{tabular}

species is also noteworthy since it was found in Black Marlins from the apparently unpolluted waters off North-Eastern Australia, with $24 \mu g . g^{-1}$ d.w. reported in its muscle tissue (Mackay et al., 1975).

\subsection{Risk to the fish and their predators}

Mercury in fish can pose health risks to the fish themselves and to their predators, including humans. Mercury levels of $5 \mu \mathrm{g} \cdot \mathrm{g}^{-1} w . w$. in fish muscle can be associated with loss of appetite, emaciation, decrease coordination and mortality in fish itself (Eisler, 1987), while levels of $15 \mu \mathrm{g} \cdot \mathrm{g}^{-1} \mathrm{w} . \mathrm{w}$. are required for provoking adverse effects in their predators (Spry and Wiener, 1991). In this study, the highest $\mathrm{Hg}$ level recorded was $2.68 \mu g \cdot g^{-1} w . w$. in a Swordfish, suggesting that $\mathrm{Hg}$ is not a threat to the fish themselves, nor to their predators. 
Since the large scale MeHg poisoning accident of Minamata in Japan in 1957, $\mathrm{Hg}$ levels in fish have been thoroughly examined in view of human consumption. In 1979, the Food and Drug Administration in the United States (US FDA) established an action level of $1 \mu g \cdot g^{-1} w \cdot w$. to regulate $\mathrm{MeHg}$ content in commercial fish. Although guidance or standards for $\mathrm{Hg}$ in fish tissues are not always uniform (Burger and Gochfeld, In Press), most international standards have, since then, adopted an action limit of $0.5 \mu g . g^{-1} w . w$. , except for predatory fish (such as billfish, tunas and other high-Hg level fish) for which the allowed level is $1 \mu g \cdot g^{-1} w . w$. (IPCS, 1987; EPA, 1994). It is recommended that the population restrains from consuming, on a regular basis, species exceeding these values. Based on this, $\mathrm{Hg}$ is considered as a potential safety hazard for Skipjacks, Halibuts, the Spanish Mackerel (Scomberomorous maculatus), the King Mackerel (S. cavalla), Marlins, Sharks, the Swordfish and the Bluefin Tuna (Mendez et al., 2001; Dua and Gupta, 2005).

Because a large percentage of $\mathrm{Hg}$ is present as $\mathrm{MeHg}$ in the edible portions of fish (Cappon and Smith, 1981; Bloom, 1992; Wagemann et al., 1997), we assumed that concentration of total $\mathrm{Hg}(\mathrm{T}-\mathrm{Hg})$ was equal to that of $\mathrm{MeHg}$ in the muscle. None of the Common Dolphinfish or Skipjacks considered in this study were above the $1 \mu g \cdot g^{-1}$ guideline. Yellowfin Tunas caught in the Mozambique Channel were also under this limit whereas, one of the 20 Yellowfin Tunas fished around Reunion Island exceeded the provisional maximum permissible level. In the Mozambique Channel and Reunion Island, 2.6\% and $42.9 \%$ of the swordfish respectively, were above the authorized limits. This last result on Reunion Swordfish should however be taken very cautiously and not generalized owing to the very small sample size (7 fish). Further analyzes should be conducted to provide a truly valid percentage. Furthermore, the body length of these fish, which is a major variation factor of $\mathrm{Hg}$ levels (Section 3.1), is to be considered when addressing the problem of potential health risks as the consumption of smaller fish reduces the amount of $\mathrm{Hg}$ ingested. Moreover, the thresholds established for $\mathrm{Hg}$ in fish muscle destinated to human consumption do not take into account the amount of fish ingested by consumers. To evaluate the potential health risk to people through consumption of these fish, $\mathrm{Hg}$ intake rates were estimated on the basis of the $\mathrm{Hg}$ levels in fish muscle (our results transformed into wet weight basis) and daily fish consumption found in the literature (Antoine, 1995; FAO, 2001; Mauritius Central Statistics Office, 2002). The daily human exposure to $\mathrm{Hg}$ from fish consumption can be calculated with the following formula:

$$
\mu g H g \cdot d a y^{-1}=\mu g H g \cdot g \text { fish }^{-1} \times g \text { fish } . d a y^{-1}
$$

Different Acceptable Daily Intake (ADI) limits have been established by national and international instances. The ADI set by the World Health Organization (WHO) for T-Hg is $0.71 \mu g . d a y^{-1} . \mathrm{kg}^{-1}$ body weight, and restricted to $0.35 \mu \mathrm{g} . \mathrm{day}^{-1} . \mathrm{kg}^{-1}$ body weight for pregnant women because foetus are more 
Table 6

Estimated daily consumption of $\mathrm{T}-\mathrm{Hg}(\mu g)$, in various countries in which people are likely to eat fish captured in the Mozambique Channel and Reunion waters. The bold values indicate the most probable consumer countries. The shadowed values are above the ADI set by the WHO. The values in dotted boxes are above the ADI set by the EPA. The countries' average yearly fish consumption per capita ( $k g$ fresh weight) is given under each country considered (Antoine 1995, Mauritius Central Statistics Office 2002, FAO \& SIDP Oct. 2005).

\begin{tabular}{|c|c|c|c|c|c|c|}
\hline \multirow[b]{2}{*}{$\begin{array}{c}\text { Yearly fish } \\
\text { consumption per capita }\end{array}$} & \multirow{2}{*}{$\begin{array}{c}\text { Mozambique } \\
6 \mathrm{Kg}\end{array}$} & \multirow{2}{*}{$\begin{array}{c}\text { Madagascar } \\
10 \mathrm{Kg}\end{array}$} & \multicolumn{2}{|c|}{ France } & \multirow{2}{*}{$\begin{array}{l}\text { Comoros } \\
19 \mathrm{Kg}\end{array}$} & \multirow{2}{*}{$\begin{array}{c}\text { Mauritius } \\
20 \mathrm{Kg}\end{array}$} \\
\hline & & & $\begin{array}{c}\text { Mainland } \\
\text { central regions } \\
7 \mathrm{Kg}\end{array}$ & $\begin{array}{l}\text { Coastal regions } \\
\& \text { Reunion } \\
15 \mathrm{Kg}\end{array}$ & & \\
\hline \multicolumn{7}{|l|}{ Mozambique } \\
\hline Swordfish & 6,23 & 10,38 & 7,27 & 15,58 & 19,73 & 20,77 \\
\hline Yellowfin Tuna & 2,20 & 3,67 & 2,57 & 5,51 & 6,98 & 7,35 \\
\hline Common Dolphinfish & 2,85 & 4,76 & 3,33 & 7,14 & 9,04 & 9,51 \\
\hline \multicolumn{7}{|l|}{ Reunion } \\
\hline Swordfish & 20,35 & 33,91 & 23,74 & $\mathbf{5 0 , 8 6}$ & 64,43 & 67,82 \\
\hline Yellowfin Tuna & 4,98 & 8,30 & 5,81 & 12,44 & 15,76 & 16,59 \\
\hline Skipjack & 3,18 & 5,30 & 3,71 & 7,95 & 10,07 & 10,60 \\
\hline Wahoo & 2,74 & 1,64 & 5,21 & 4,11 & 4,11 & 1,92 \\
\hline Common Dolphinfish & 0,22 & 0,37 & 0,26 & $\mathbf{0 , 5 5}$ & 0,70 & $\mathbf{0 , 7 4}$ \\
\hline
\end{tabular}

sensitive to $\mathrm{Hg}$ toxicity, for nursing mothers, and for children less than 10 years (Chan, 1998; DHHS and EPA, 2004). The French (AFSSA) and the Canadian health agencies follow the same guidelines as the WHO, whereas the U.S. FDA and U.S. Environmental Protection Agency (EPA) have set more restrictive ADI limits for $\mathrm{MeHg}\left(0.4\right.$ and $0.1 \mu g . d a y^{-1} . \mathrm{kg}^{-1}$ body weight respectively for all the population) (Hirsch, 2002).

Considering an average adult body weight of $70 \mathrm{~kg}$ (EPA, 1994), the $\mathrm{T}-\mathrm{Hg}$ WHO ADI can be approximated as $50 \mu g . d a y^{-1}$. adult ${ }^{-1}$. This health risk limit was compared to the estimated daily consumption of $\mathrm{Hg}$ in various countries where fish originating from the two study zones are susceptible to be eaten (Table 6). The $\mathrm{T}-\mathrm{Hg}$ values exceeding the most restrictive guidlines set by the

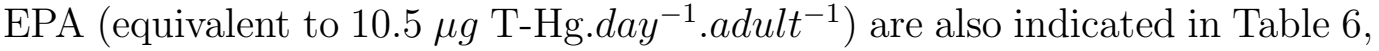
but will not be discussed. Only 4 of the 7 locations seemed confronted with potential health risks due to $\mathrm{Hg}$, i.e. Reunion and Coastal Mainland France. Furthermore, these conclusions are valid only if the population's fish intake is restricted to Swordfish caught in Reunion waters. This obviously rarely represents the reality. For example, inhabitants of the Comoros and Creoles from Reunion Island, chiefly eat demersal fish (Ministère de la production et de l'environnement, 2000). French living on Mainland France do favor pelagic fish such as Tuna, Marlin and Swordfish, but also eat local demersal fish (Antoine, 1995). Moreover, the risk for human health can be minimized if the consumption of Swordfish is limited to a certain size. For example, given the limited data in this study, $\mathrm{Hg}$ levels seem to exceed the permissible level only in individuals measuring more than $132 \mathrm{~cm}$ in length (Figure 2). For smaller Swordfish the health risk is considered as null, with average daily $\mathrm{Hg}$ 
Table 7

Safety limits (WHO), expressed as the frequency of meals for which fish is the main element, based on an adult standard portion size of $230 \mathrm{~g}$. These estimations do not apply for pregnant woman and children.

\begin{tabular}{lcc}
\hline & \multicolumn{2}{c}{ Hg safety limits } \\
& Mozambique & Reunion \\
\hline Swordfish & 4 meals per week & 1 meal per week \\
Yellowfin Tuna & 1 meal per day & 1 meal per day \\
Skipjack Tuna & & 1 meal per day \\
Wahoo & & 1 meal per day \\
Common Dolphinfish & 1 meal per day & $>3$ meals per day \\
\hline
\end{tabular}

intakes per capita of $28.78 \mu \mathrm{g}$ in Reunion and coastal France, $36.45 \mu \mathrm{g}$ in Comoros and $38.37 \mu \mathrm{g}$ in Mauritius. In the same way, Western Indian Ocean Yellowfin Tunas measuring less than $224 \mathrm{~cm}$ should be under the $1 \mu \mathrm{g} \cdot \mathrm{g}^{-1}$ advisory level, as would be Skipjacks, Wahoos and Common Dolphinfish of any size. There is, however, a non negligible drawback in encouraging the consumption of small Swordfish since most of these individuals are immature: the smallest mature female recorded in the Western Indian Ocean measured $127 \mathrm{~cm}$ LJFL (Taquet, 2003). Targeting immatures can pose a great threat to the entire Swordfish stock.

In order to better appreciate the amounts of fish safe for consumption, exposure limits can be expressed as the number of meals that an adult can eat per day, or per week, and be under the $50 \mu \mathrm{g} \mathrm{Hg} \cdot d a y^{-1}$ ADI (hence

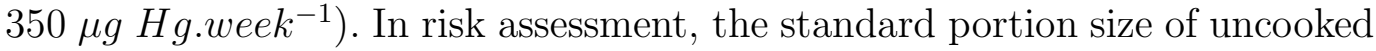
fish eaten by an average adult is estimated to be $230 \mathrm{~g}$ (EPA, 1994; Brodberg and Klasing, 2003). Safety limits, expressed as the frequency of meals for which fish is the main element, based on the $\mathrm{Hg}$ levels reported in this study are given in Table 7. For individuals weighing more, or less, than $70 \mathrm{~kg}$, it is assumed that their consumption rates will be proportionally higher or lower, respectively, yielding an overall similar exposure level following the consumption of equally contaminated fish (Brodberg and Klasing, 2003).

Nevertheless, consumers should bear in mind that standards have a safety margin. A concrete example of the limitations of the guidelines for $\mathrm{Hg}$ is given by two decades of investigation on the neighboring Seychellois population. During the Seychelles Child Development study, 779 children from the Seychelles whose mothers ate great amounts of $\mathrm{Hg}$-contaminated fish $\left(0.3 \mu g \cdot g^{-1} w . w\right.$. mean content) during their pregnancies (on average 12 meals per week) were followed from birth to adulthood and showed no significant evidence of verbal, motor, memory or reasoning skills deficits (Matthews, 1983; Myers et al., 2003; Shamlaye et al., 2004). Furthermore, a dietary survey carried out with 26 adult women from a fish-eating community in the Brazilian Amazon indicated that eating tropical fruit reduced $\mathrm{Hg}$ exposure from fish consumption 
(Passos et al., 2003).

\section{Conclusion}

This study confirms that Swordfish has high $\mathrm{Hg}$ levels in comparison with most other pelagic fish. The large size of this species is one of the main explanatory factor of the high $\mathrm{Hg}$ burdens as they increases with fish length. Besides, the Swordfish was the only species for which clear differences in $\mathrm{Hg}$ levels were noted between fish from both study areas.

As far as human safety is concerned, the results of this study suggest that consumers of fish originating from the South Western Indian Ocean should limit themselves to one meal a day if they consume tunas, Wahoo or Common Dolphinfish, or one meal a week if they eat Swordfish. Pregnant women, nursing mothers and children should limit their consumption of the largest pelagic species. Mercury level determination would be of interest in other edible tissues such as liver and gonads where $\mathrm{Hg}$ is known to accumulate (Cizdziel et al., 2003; Bustamante et al., 2003). Further investigations should also include other large commercialized teleost species such as Marlins. In any case, consumers should bear in mind that standards have a margin of safety and that fish provides essential nutrients such as Omega-3 fatty acids, phosphorus, calcium, and various vitamins and minerals. Moreover, fish constitutes an important source of protein, and is often the main livelihood for many people throughout the world. For these reasons, it is important to adapt $\mathrm{Hg}$ thresholds to local population's true exposure levels.

\section{Acknowledgments}

This research was supported by the Conseil Général de La Réunion. J.K. also benefited from support of the Conseil Régional de La Réunion and the European Social Fund through a $\mathrm{PhD}$ grant. The authors would like to thank J. Bourjea and M. Taquet (Ifremer - La Réunion), as well as Maeva Pêche au Gros, Réunion Fishing Club, L. \& P. Berthier, and other anonymous Reunionese fisherman for their assistance in the sampling effort. We would also like thank C. Churlaud, (Centre Commun d'Analyse - La Rochelle), E. Robert, M. Rouquette, P. Grondin and N. Ghanem (University of La Réunion) for their help in the sample preparation and analysis. We would also like to thank the referees for helpful comments on the manuscript. 


\section{References}

Antoine, C., 1995. Données actuelles des ichtyosarcotoxismes à la Réunion. Revue de 153 observations. Ph.D. thesis, Université Paris XI, Faculté de Médecine Paris-Sud, doctorat en Médecine.

Bloom, N. S., 1992. A survey of size-specific mercury concentrations in game fish from Maryland fresh and estuarine waters. Arch. Environ. Contam. Toxicol. 39 (1), 53-59.

Boudou, A., 1982. Recherche en écotoxicologie expérimentale sur les processus de bioaccumulation et de transfert des dérivés du mercure dans les systèmes aquatiques continentaux. Ph.D. thesis, Université de Bordeaux I, doctorat d'Etat ès Sciences.

Brodberg, R., Klasing, S., 2003. Evaluation of potential health effects of eating fish from Black Butte reservoir (Glenn and Tahama counties): guidelines for sport fish consumption. Tech. rep., Pesticide and Environmental Toxicology Section, Office of Environmental Health Hazard Assessment, California Environmental Protection Agency.

Burger, J., Gochfeld, M., In Press. Heavy metals in commercial fish in new jersey. Env. Res .

Bustamante, P., Bochet, P., Cherel, Y., Miramand, P., Caurant, F., 2003. Distribution of trace elements in tissues of benthic and pelagic fish from the Kerguelen Islands. Sci. Total Environ. 313, 25-39.

Cappon, C. J., Smith, J. C., 1981. Mercury and selenium content and chemical form in fish muscle. Arch. Environ. Contam. Toxicol. 10 (3), 305-319.

Chan, H. M., 1998. Metal accumulation and detoxification in humans. In: Metal metabolism in aquatic environments. Ecotoxicology series, 7. Chapman and Hall, London UK, pp. 415-438.

Cizdziel, J., Hinners, T., Cross, C., Pollard, J., 2003. Distribution of mercury in the tissues of five species of freshwater fish from Lake Mead, USA. J. Environ. Monit. 5 (5), 802-807.

Conand, F., Tessier, E., 1996. Les DCP à l'île de La Réunion: histoire, évolution, influence sur les prises et l'activité de la pêche côtière. In: Dispositif de concentration de poissons. Vol. 1 of Bulletin de la CPS. Département des pêches de la CPS, Nouméa, Nouvelle-Calédonie, pp. 3-6.

De Martini, E. E., Boggs, C. H., 1999. Biological research in support of swordfish stock assessment. Tech. rep., National Marine Fisheries Service, Honolulu, Hawaii, document ISC/99/3.2 submitted at the Second Meeting of the Interim Scientific Committee for Tuna and Tuna-like Species in the North Pacific Ocean.

DHHS, EPA, 2004. What you need to know about mercury in fish and shellfish. Tech. rep., U.S. Department of Health and Human Sevirces and U.S. Environmental Protection Agency, U.S.A.

Dietz, R., Riget, F., Johansen, P., 1996. Lead, cadmium, mercury and selenium in Greenland marine animals. Sci. Tot. Environ. 186, 67-93.

Dracobly, A., 2004. Theoretical change and therapeutic innovation in the treat- 
ment of syphilis in mid-nineteenth-century France. J. Hist. Med. All. Sci. 59 (4), 522-554.

Dua, A., Gupta, N., 2005. Mercury toxicology as assessed through fish scales. Bull. Environ. Contam. Toxicol. 74 (6), 1105-1110.

Durrieu, G., Maury-Brachet, R., Boudou, A., 2005. Goldmining and mercury contamination of the piscivorous fish Hoplias aimara in French Guiana (Amazon basin). Ecotox. Environ. Safety 60 (3), 315-323.

Eisler, R., 1987. Mercury hazards to fish, wildlife, and invertebrates: a synoptic review. Biol. Rep. 85 (2), 1-10.

EPA, 1994. Guidance for assessing chemical contaminant data for use in fish advisories. Volume II. Risk assessment and fish consumption limits. Tech. rep., U.S. Environmental Protection Agency, Office of Water, Philadelphia, PA.

FAO, 2001. Consultation technique sur les cadre juridique et les politiques économiques à adopter pour promouvoir une aquaculture commerciale durable en afrique subsaharienne. Tech. rep., FAO, Arusha, Tanzanie.

FAO, SIDP, Oct. 2005. Fisheries global information system, Species identification sheets.

URL http://www.fao.org/figis/servlet/static?dom=root\&xml=species/index.xml

Faraway, J. J., 2005. Linear Models with R. Chapman and Hall/CRC, Florida, U.S.A.

Freeman, H. C., Home, D. A., 1973. Sampling the edible muscleof the swordfish (Xiphias gladius) for the total mercury content. J. Fish Res. Bd. Can. 30, 1251-1252.

Gaertner, J.-C., Poisson, F., Taquet, M., 2001. Analyse des interactions entre les captures de grands pélagiques de la flotille palangrière réunionnaise et les conditions de pêche (caractéristiques techniques, environnement). In: L'espadon: de la recherche à l'exploitation durable. Ifremer, France, pp. 106-127.

Gilmour, C. C., Riedel, G. S., 2000. A survey of size-specific mercury concentrations in game fish from Maryland fresh and estuarine waters. Arch. Environ. Contam. Toxicol. 39 (1), 53-59.

Hirsch, M., 2002. Avis de l'agence française de sécurité sanitaire des aliments relatif à l'évaluation des risques sanitaires liés à l'exposition au mercure des femmes enceintes et allaitantes et des jeunes enfants. Tech. rep., AFSSA.

IPCS, 1987. Principle for safety assessment of food additives and contaminants in food. Tech. rep., International Programme on Chemical Safety in cooperation with the Joint FAO/WHO Expert Committee on Food Additives (JECFA).

Jaffar, M., Ashraf, M., 1988. Selected trace metal concentrations in different tissues of fish from coastal waters of Pakistan (Arabian Sea). Indian J. Mar. Sci. 17, 231-234.

Kehrig, H. A., Costa, M., Moreira, I., Malm, O., 2002. Total and methylmercury in a Brazilian estuary, Rio de Janeiro. Mar. Pollut. Bull. 44 (10), 
$1018-1023$.

Kraepiel, A. M. L., Keller, K., Chin, H. B., Malcolm, E. G., Morel, F. M. M., 2003. Sources and variations of mercury in tuna. Environ. Sci. Tech. 37 (24), $5551-5558$.

Kume, S., Joseph, J., 1969. Size composition and sexual maturity of billfish caught by the Japanese longline fishery in the Pacific Ocean est of $130^{\circ} \mathrm{W}$. Bull. Far Seas Fish. Res. Lab. 2, 115-162.

Kureishy, T. W., George, M. D., Sen Gupta, R., 1979. Total mercury content in some marine fish from the Indian Ocean. Mar. Poll. Bull. 10, 367-360.

Mackay, N. J., Kazacos, M. N., Williams, R. J., Leedow, M. I., 1975. Selenium and heavy metals in black marlin. Mar. Poll. Bull. 6 (4), 57-61.

Matthews, A. D., 1983. Mercury content of commercial important fish of the Seychelles, and hair mercury levels of a selected part of the population. Environ. Res. 30, 305-312.

Mauritius Central Statistics Office, 2002. Digest of environment statistics 2002. Tech. rep., Ministry of Finance and Economic Development.

Mendez, E., Giudice, H., Pereira, A., Inocente, G., Medina, D., 2001. Total mercury content - fish weight relationship in swordfish (Xiphias gladius) caught in the Southwest Atlantic Ocean. Journ. Food Comp. Anal. 14 (5), 453-460.

Mercury Task Force, 2002. Impact of mercury on public health in New Jersey. Tech. rep., New Jersey Department of Environmental Protection.

Ministère de la production et de l'environnement, 2000. Stratégie nationale et plan d'action pour la conservation et la diversité biologique. Tech. rep., République Fédérale Islamique des Comores.

Monteiro, L. R., Costa, V., Furness, R. W., Santos, R. S., 1996. Mercury concentrations in prey fish indicate enhanced bioaccumulation in mesopelagic environments. Mar. Ecol. Prog. Ser. 141, 21-25.

Monteiro, L. R., Lopes, H. D., 1990. Mercury content of Swordfish, Xiphias gladius, in relation to length, weight, age and sex. Mar. Poll. Bull. 21 (6), 293-296.

Mormede, S., Davies, I. M., 2001. Trace elements in deep-water fish species from the Rockall Trough. Fish. Res. 51 (2-3), 197-206.

Muus, B.-J., Nielsen, J.-G., Dahlstrom, P., Olesen Nyström, B., 1998. Guide des poissons de mer et pêche. Delachaux et Niestlé, Lausanne-Paris.

Myers, G. J., Davidson, P. W., Cox, C., Shamlaye, C. F., Palumbo, D., Cernichiari, E., Sloane-Reeves, J., Wilding, G. E., Kost, J., Huang, L.-S., Clarkson, T. W., 2003. Prenatal methylmercury exposure from ocean fish consumption in the Seychelles child development study. Lancet 361 (9370), 1686-1692.

NOAA fisheries, Oct. 2005. National marine fishery service.

URL http://www.nmfs.noaa.gov

Opic, P., Conand, F., Bourret, P., 1994. Poissons commerciaux du sud-ouest de l'Océan Indien. ORSTOM ed.

Passos, C. J., Mergler, D., Gaspar, E., Morais, S., Lucotte, M., Larribe, F., 
Davidson, R., de Grosbois, S., 2003. Eating tropical fruit reduces mercury exposure from fish consumption in the Brazilian Amazon. Environ. Res. 93 (2), 123-130.

Pianet, R., 1998. Etat des stocks de thonidés dans l'Océan Indien. In: Le thon: enjeux et stratégies pour l'Océan Indien. Orstom, Paris, pp. 75-138.

Quéro, J.-C., Vayne, J.-J., 1997. Les poissons de mer des pêches françaises, identification, inventaire et répartition de 209 espèces. Delachaux et Niestlé, Paris.

R Development Core Team, 2005. R: A language and environment for statistical computing. R Foundation for Statistical Computing, Vienna, Austria, ISBN 3-900051-07-0.

URL http://www.R-project.org

Shamlaye, C., Davidson, P. W., Myers, G. J., 2004. The Seychelles child development study: two decades of collaboration. Seychelles Medical and Dental Journal 7 (1), 92-98.

Spry, D. J., Wiener, J. G., 1991. Metal bioavailability and toxicity to fish in low-alkalinity lakes: A critical review. Environ. Poll. 71 (2-4), 243-304.

Stafford, C. P., Haines, T. A., 2001. Mercury contamination and growth rate in two piscivore populations. Environ. Toxicol. Chem. 20, 2099-2101.

Stéquert, B., Marsac, F., 1986. La pêche de surface des thonidés tropicaux dans l'Océan Indien. Tech. Rep. 282, FAO.

Svensson, B. G., Schütz, A., Nilsson, A., Åkesson, I., Åkesson, B., Skerfving, S., 1992. Fish as a source of exposure to mercury and selenium. Sci. Tot. Environ. 126 (1-2), 61-74.

Taquet, M., 2003. Dorade coryphène commune (Coryphaena hippurus). Tech. rep., Ifremer.

Vanpouille, K., Poisson, F., Taquet, M., Ogor, A., Troadec, H., 2001. Etude de la croissance de l'espadon (Xiphias gladius). In: Etude des caractéristiques biologiques de l'espadon (Xiphias gladius) dans le sud-ouest de l'Océan Indien. Vol. 205. Ifremer, France, pp. 139-169.

Venables, W. N., Ripley, B. D., 2002. Statistics and computing. Modern applied statistics with S. Springers, New York, U.S.A., fourth edition.

Wagemann, R., Trebacz, E., Hunt, R., Boila, G., 1997. Percent methylmercury and organic mercury in tissues of marine mammals and fish using different experimental and calculation methods. Environ. Toxicol. Chem. 16 (9), 1859-1866.

Ward, P., Elscot, S., 2000. Broadbill swordfish, status of world fisheries. Tech. rep., Bureau of Rural Sciences.

Weenarain, S., Cayré, P., 1998. Impact économique des activité thonières industrielles. In: Le thon: enjeux et stratégies pour l'Océan Indien. Orstom, Paris, pp. 177-122. 